\title{
Süleyman Demirel Üniversitesi Tıp Fakültesi Sağlık Personelinin Organ Bağışına Bakışı
}

\author{
Selami KARA ${ }^{1}$, Zeliha SALMAN ${ }^{2}$ ve Kurtuluş ÖNGEL $L^{3}$

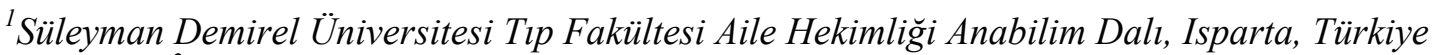 \\ ${ }^{2}$ Süleyman Demirel Üniversitesi Tip Fakültesi Aile Hekimliği Anabilim \\ Dall, Isparta, Türkiye \\ ${ }^{3}$ T.C. Sağllk Bakanlığ Tepecik Eğitim ve Araştırma Hastanesi Aile \\ Hekimliği Kliniği, İzmir, Türkiye
}

\begin{abstract}
Özet
Organ/doku nakli (transplantasyon); vücutta görevini yapamayan bir organın/dokunun yerine canlı kişiden, beyin ölümü gerçekleşmiş kişiden ya da ölüden alınan sağlam ve aynı görevi üslenecek bir organın/dokunun nakledilmesi işlemidir. Bu çalışma sağlıkta son basamak olan bir tıp fakültesi hastanesi çalışanlarının organ bağışına karşı tutumlarını, bilgilerini ve bakışlarını tespit etmek amacıyla planlanmıştır. Çalışma Eylül-Kasım 2009 tarihleri arasında Süleyman Demirel Üniversitesi Tıp Fakültesi Hastanesi'nde yapılmıştır. Çalışmaya ilgili tarihlerde tıp fakültesinde görev yapan toplam 536 personel dahil edilmiştir. Çalışmaya katılanların \%24,8'i (n:133) doktor, \%17,2'si (n:92) hemşire ve sağlı memuru, \%58'i (n:311) yardımcı personel olarak görev yapmaktaydı. Nakli yapılabilen organlar sorgulandığında; \%100 (n:536) böbrek, \%80 (n:429) karaciğer, \%82,8(n:444) kalp, \%26,1 (n:140) pankreas, \%27,6 (n:148) akciğer, \%13,4 (n:72) ince barsak, \%73,7 (n:395) kornea, \%17,7 (n:95) kemik, \%36,7 (n:197) deri, \%15,3(n:82) sinir, \%77,7 (n:416) kemik iliği cevabı alınmıştır. Ailesinde/çevresinde organ nakli olan kişiler ile ailesinde/çevresinde organ nakli bekleyen hastası olanlar ve ailesinde organ bağışı yapmış olan kișiler anlamlı olarak daha fazla organ bağışında bulunmak istemektedirler (p:0.002, p:0.011, p:0.000). Toplumun organ bağışı hakkındaki düşünceleri, bilgisi, varsa organ bağışını ve katılımlarını olumsuz yönde etkileyen faktörlerin belirlenmesi gerekmektedir. Toplumun gelenek, görenek ve inançlarının organ bağışını etkileyip etkilemediği, etkiliyor ise hangi yönde etkilediğinin araştııılması organ bağışını artırmaya yönelik çalışmalara temel oluşturması açısından önemli ve gereklidir.
\end{abstract}

Anahtar Kelimeler: Organ Transplantasyonu, Donör, Doku Uyumu, Farkındalık.

\begin{abstract}
Organ or tissue transplantation is the moving of an organ or tissue from one body to another who is either dead or only his/her brain is dead, or from a donor site on the patient's own body, for the purpose of replacing the recipient's damaged or absent organ. In this study we observed the viewpoints of Faculty of Medicine staff who are the last defense line of human health, to organ donation. The study has been done in 2009 between September to November at the Suleyman Demirel University, Faculty of Medicine, Research and Application Hospital. During this period, it has been reported that there were 536 people working at the hospital. It has been recorded that there were $133(24,8 \%)$ doctors, $92(17,2 \%)$ nurses and medical officers and $311(58 \%)$ other staff included in the study. When we ask which organs would they choose to donate, the data as follows: Kidney: 100\% (n.536), Liver: 80\% (n.429), Heart: 82,8\% (n.444), Pancreas: 26,1\%
\end{abstract}


(n:140), Lungs: 27,6\% (n:148), Small intestine: 13,4 (n:72), Cornea:73,7\% (n:395), Bones: 17,7\% (n:95), Skin: 36,7\% (n:197), Neuron: 15,3 (n:82), Bone marrow: 77,7\% (n:416). The data of the number of staff who know patients that received an organ transplant, the staff who know patients that are expecting an organ transplant and the staff who has a family member willingly donated organs, suggest that there is a significant tendency of donating more organs (p:0.002, p:0.011, $\mathrm{p}: 0.000)$. It is a requirement to observe the viewpoint, the knowledge and organ donation rate if there is any of the entire society about the organ donation. Additionally the factors that affect the donation decision negatively upon society must be identified also. There are ethical factors such as costumes, traditions and beliefs that may affect the organ donation. However we do not know how they affect the viewpoint of the society. Thus it is important and a requirement that these factors must be observed.

Keywords: Organ Transplantation, Donor, Tissue Adaptation, Awareness.

\section{Giriş}

Organ-doku nakli (transplantasyon); vücutta görevini yapamayan bir organın-dokunun yerine canlı kişiden, beyin ölümü gerçekleşmiş kişiden ya da ölüden alınan sağlam ve aynı görevi üslenecek bir organın-dokunun nakledilmesi işlemidir. Organ nakli, organ yetmezliği olan hastalar için son şans olarak görülmektedir (1). Bir kişinin hayatta iken serbest iradesi ile tıbben yaşamı sona erdikten sonra doku ve organlarının başka hastaların tedavisi için kullanılmasına izin vermesi ve bunu belgelendirmesi organ-doku bağışı olarak adlandırılmaktadır (2). Organ naklinin amacı, organ yetmezliği nedeniyle yaşam kalitesi düşmüş ve yaşamın sonuna gelmiş hastaların hayatını kurtarmak, yaşam süresini ve kalitesini arttırmaktır (3).

Organ transplantasyonu, canlı vericiden ve kadavradan olmak üzere iki şekilde yapılır. Canlı vericiden organ naklinde organ yaşamakta olan sağlıklı bir kişiden alınır. Genellikle 4. dereceye kadar yakın akrabalardan uygun organlarından birinin alınıp nakil yapılabilmesine kanunlar izin vermektedir (4). Kadavradan organ naklinde ise organları alınan kişi tıbben ölmüştür. Bağışta bulunduğu organlar ihtiyacı olan ve doku uyumu bulunan hastalara nakledilir (4).

Organ ve doku nakline yönelik çalışmalar ilk defa 1900'lü yılların başlarında başlamıştır (5). İlk ciddi organ nakli denemesi ise böbrek nakli ile Viyana'da 1902'de hayvanlar üzerinde ve Rusya'da 1933 'te ölüden canlıya gerçekleştirilmiştir (6). Dünya'da canlı insandan böbrek nakli ilk defa 1947'de ve ilk başarılı kalp nakli 1967'de Amerika Birleşik Devletleri'nde yapılmıştır (7). Türkiye'de ilk organ nakli girişimi 1962 'de Dr. Kemal Beyazıt tarafından yapılan kalp naklidir, ancak nakil sonrası hasta kaybedildiği için bu nakil başarısız olarak kayıtlara geçmiştir (8). 1970'lerin başında Hacettepe Üniversitesinde hayvanlar üzerinde organ nakli deney çalışmaları başlamış ve ilk başarılı organ nakli 1975'de Dr. Mehmet Haberal tarafından bir anneden oğluna böbrek nakledilmesi ile gerçekleştirilmiştir (9).

Organ ve doku nakli, bir ülkenin gelişmişlik düzeyini gösteren önemli ölçütlerdendir. Organ ve doku naklinin yasal, etik, tıbbi, sosyal, psikolojik, teknolojik, ekonomik ve dini yönlerden başarısı, organ ve doku naklinin başarısı ile doğru orantılı olarak değerlendirilmektedir (10).

Birçok ülke, organ bağışı ve transplantasyon ile ilgili yasal düzenlemelerini oluşturmuştur. İspanya'da, İsveç’te, Almanya'da ve Avrupa komisyon toplantı kurallarına (Porto 2000) göre diğer Avrupa ülkelerinde organ bağışı, beyin ölümü ve organ nakli ile ilgili yasal düzenlemeler yapılmıştır (11). Türkiye'de organ nakli; 29.05.1979 tarihli "Organ ve Doku Alınması, Saklanması ve Nakli Hakkında" 2238 sayılı kanun ile 1982 yılında yeniden düzenlenen maddelere (3). ve 1 Haziran 2000 tarih ve 24066 sayıll Resmi Gazetede yayınlanarak 07.03.2005, 24.10.2007 ve 11.03.2009 tarihlerinde değişikliğe uğrayan "Organ ve Doku Nakli Hizmetleri Yönetmeliği” doğrultusunda yapılmaktadır. Bu çerçevede Sağlik Bakanlığı tarafindan ilgili birimlere gönderilen genelgelerle organ bağışı, nakli ve beyin ölümü hakkında bilgilendirme yapılmaktadır (4). Ayrıca ülkemizde Diyanet İşleri Yüksek Kurulu 1980 yılında 396 sayılı kararı ile organ naklinin caiz olduğu bildirilmiştir (12).

Türkiye'de 2007 yılı verilerine göre organ bağış kartı alan kişi sayısı 51,000'dir. Kartların 35,200 'ü İstanbul ilinden alınmıştır. Kadavra donör sayısı ise 245 kişi (3/1000000) olarak belirtilmiştir 
(13). Organlarını bağışlayanlar arasında \%35,4'lük oranla 18-27 yaş arası grup başı çekmekte ve onları \%26,7 ile 28-37 yaş arası grup takip etmektedir (10). Bağışlanan organlar, doku ve kan gurubu uygunluğuna göre acil bekleyen hastalara nakledilirler. Organ paylaşımı Ulusal Koordinasyon Sistemi tarafindan tıbbi açıdan acil olma durumu, gerekli durumlarda doku ve kan grubu uyumu, din, dil, ırk, cinsiyet, zengin-fakir ayırımı gözetmeden dağıtım yapılmaktadır $(4,13)$.

Her ölen kişinin organı, organ bağışı için uygun olmadığı için organ bağışında bulunan herkesin organlarının kullanılacağına dair bir durum söz konusu değildir. Geri dönüşü olmayacak şekilde beyin hasarı (beyin ölümü) olan ve hastane şartlarında ölen kişilerin organları, ilgili uzmanların beyin ölümü tanısı koyması ve ailesinin izin vermesiyle nakil yapılabilir (14). Organ alınabilmesi için tıbbi ölümün gerçekleşmesi gerekmektedir. Tıbbi ölüm kararını, ülkemizde 2238 sayılı yasa gereği 4 kişilik hekimler kurulu oybirliği ile vermektedir (3).

Organ bağış1 yapılırken, doldurulan kartın üzerinde bağış yapılan organlar işaretlenerek kişinin tercihlerine göre organlar sınırlandırılarak bağışlanabilir. Kart üzerinde böbrek, karaciğer, pankreas, kalp, akciğer, kornea gibi organların isimleri işaretlenerek sadece organlar tercih edilebileceği gibi hepsi seçeneği de işaretlenerek tamamı bağışlanabilir. Tamamının bağışlanması durumunda en az 8 kisiye yeni bir hayat verilebilir. Eğer kişi organ bağışlamaktan vazgeçerse bağış kartının yırtılıp atılmasi yeterlidir (3). Alınan organlar, organ bekleme listesinde kan grubu ve doku tipi uyumu olan kişilerden en uygun olana nakledilmektedir. Merkezler arasında organ nakli koordinatörleri aracılığıla iletişim sağlanarak kan grubu ve doku tipi uyumu en fazla olan alıcı bulunmaya çalışılmaktadır (15).

Ülkemizde yapılan organ nakillerinin yaklaşı \%75-80'inden fazlası canlı kişilerden alınan organlarla gerçekleşirken; Avrupa ülkelerinde nakillerin \%80'inden fazlası kadavradan alınan organlarla yapılmaktadır (16). Organ nakli ve organ bağışı konusunda eğitime önem veren ve bu konuda toplumda belirli bilinç düzeyi oluşturulmuş ülkelerde kadavradan organ bağışı oranları yüksektir. Organ Nakli Koordinatörler Derneği (ONKOD) 2004 verilerine göre; milyon nufus başına kadavra donör sayıları (pmp); İspanya'da 34,6, İtalya'da 21,1, Fransa'da 20,9, İngiltere'de 12,3, Almanya'da 13,8, Yunanistan'da 6,2, Romanya'da 0,4, Türkiye'de 2,0'dır (17). Avrupa Konseyi verilerine göre 2007 kadavra organ bağışı milyonda kişi başına; İspanya'da 34,3, Belçika'da 28,2, Fransa'da 25,3 iken Türkiye'de 3,0'dır (13). Ülkemizde kadavradan organ bağış1 çok düşüktür. Kadavra organ sayısını arttırmak ancak düzenli bir organizasyon ve ekip çalışmasıyla mümkündür (18). Organ bağışında insan faktörü çok önemlidir. İnsanların yaşadığı toplumun sosyo-kültürel özellikleri dikkate alınarak organ bağışı konusunda bilinçlendirmeyi sağlayacak eğitim planlanmalıdır. Organ nakli konusunda toplumsal bilincin yaratılmasında en iyi yol eğitimin ilköğretimden başlatılmasıdır (10). Yapılan çalışmalarla; eğitim düzeyi arttıkça, organ bağışı sürekli gündemde tutularak toplum eğitimine önem verildikçe organ bağışının arttığı ortaya konmuştur (17).

$\mathrm{Bu}$ çalışma sağlıkta son basamak olan tıp fakültesi hastanesi personel ve doktorlarının organ bağışına karşı tutumlarını, bilgilerini ve bakışlarını tespit etmek ve gerekli bilgilendirmeler yapılarak topluma eğitim verecek bu kişilerin organ bağışı hakkında bilinçlendirilmeleri ve konunun gündemde tutulması amacıyla yapılmıştır.

\section{Materyal ve Yöntem}

Çalışma Eylül-Kasım 2009 tarihleri arasında Süleyman Demirel Üniversitesi (SDÜ) Tıp Fakültesi Hastanesi'nde, SDÜ Tıp Fakültesi Aile Hekimliği Anabilim Dalı'nın desteği ile gerçekleştirilmiştir. SDÜ Tıp Fakültesi Hastanesi, Isparta İl merkezinde yeralan çevresindeki Burdur, Afyon ve Denizli illerine de hizmet veren merkezi bir konumdadır. Hastanede şu an için organ ve doku nakli yapılmamakla birlikte; organ ve doku naklinin gerçekleştirildiği Akdeniz Üniversitesi Tıp Fakültesi Hastanesi'ne yaklaşık $120 \mathrm{~km}$. uzaklıktadır. Hastanede bulunan organ ve doku nakil merkezi; bağışçılardan kayıt alarak bu kayıtların bildirimini yapmaktadır. Ayrıca beyin ölümü gerçekleşmiş kişilerin yakınları ile görüşmeler yapılarak, bu kişiler organ ve doku nakline teşvik edilmeye çalışılmaktadır. Uygun donör bulunduğu taktirde Akdeniz Üniversitesi'nde bulunan nakil merkezi ile koordinasyonu da hastanedeki bu merkez sağlamaktadır. 
Çalışma ilgili tarihlerde Tıp Fakültesi kadrosunda sağlık hizmetlerinde görev yapan personel üzerinde yapılmıştır. Çalışmada örnekleme gidilmemiş, belirtilen kadroda görev yapan tüm sağlık personeline ulaşılması hedeflenmiştir. Tüm sağlık personeline, anket formları ile birlikte çalışma konusunda açıklayıcı bilgi verilmiş, sözel olarak olurları alınan personel çalışmaya dahil edilmiştir. Kendi isteği ile çalışmaya katılmak istemeyenler, çalışmanın dışlanma kriterini oluşturmaktadır. Çalışmaya \%24,8'i (n:133) doktor, \%17,2'si (n:92) hemşire ve sağlık memuru, \%58'i (n:311) yardımc1 personel olmak üzere 536 kişi katılmıştır. Süleyman Demirel Üniversitesi Tıp Fakültesi personelinin organ bağışı ve nakli hakkındaki bilgi ve tutumlarını ölçmeye yönelik 11'i kapalı, 3 tanesi açık uçlu olmak üzere, 14 soruluk bir anket formu hazırlanarak, uygulanmış ve sonuçları değerlendirilmeye çalışılmıştır. Elde edilen veriler SPSS 15.0 programı ile çözümlenmiş ve istatistiksel olarak değerlendirilmiştir.

\section{Bulgular}

Çalışmaya katılanların \%24,8'i (n:133) doktor, \%17,2'si (n:92) hemşire ve sağlık memuru, $\% 58$ 'i (n:311) personel olmak üzere 536 kişi çalışmaya katılmıştır. Görev süreleri ortalaması $45 \pm 44.8$ ay (min:1 - max:288 ay) olarak tespit edildi.

Tablo 1. Sağlık personelinin anket sorularına verdikleri cevaplar.

\begin{tabular}{|c|c|c|c|}
\hline Soru & Cevap & n & $\%$ \\
\hline \multirow{3}{*}{ Organ bağışı nasıl bir davranış şeklidir? } & Doğru bir davranış. & 440 & 82,1 \\
\hline & Yanlış bir davranış. & 15 & 2,8 \\
\hline & Fikrim yok. & 81 & 15,1 \\
\hline \multirow{4}{*}{ Organ bağışlama kriteri nedir? } & $\begin{array}{l}\text { Kişinin hayattayken organlarını } \\
\text { bağışlamış olması gerekir. }\end{array}$ & 242 & 45,1 \\
\hline & $\begin{array}{l}\text { Ölen kişinin ailesinden izin } \\
\text { almak gerekir. }\end{array}$ & 144 & 26,9 \\
\hline & Herhangi bir izine gerek yoktur. & 10 & 1,9 \\
\hline & $\begin{array}{l}\text { Hem ölen kişi organlarını } \\
\text { bağışlamış olmalı, hem de ailenin } \\
\text { izni olmalı. }\end{array}$ & 314 & 58,6 \\
\hline \multirow{2}{*}{ Her ölen kişiden organ alınabilir mi? } & Evet & 47 & 8,8 \\
\hline & Hayır & 489 & 91,2 \\
\hline \multirow{11}{*}{ Hangi organların nakli yapılabilmektedir? } & Böbrek & 536 & 100 \\
\hline & Karaciğer & 429 & 80 \\
\hline & Kalp & 444 & 82,8 \\
\hline & Pankreas & 140 & 26,1 \\
\hline & Akciğer & 148 & 27,6 \\
\hline & İnce barsak & 72 & 13,4 \\
\hline & Kornea & 395 & 73,7 \\
\hline & Kemik & 95 & 17,7 \\
\hline & Deri & 197 & 36,7 \\
\hline & Sinir & 82 & 15,3 \\
\hline & Kemik iliği & 416 & 77,7 \\
\hline \multirow{4}{*}{ Organ bağışı ile ilgili bilgilerinizi nereden aldınız? } & Basın yayın organları & 196 & 36,5 \\
\hline & Okul ve/veya sağlık kuruluşları & 99 & 18,5 \\
\hline & Arkadaşlar & 118 & 22 \\
\hline & Boș & 213 & 39,7 \\
\hline \multirow{2}{*}{ Organ bağışı nerede ve nasıl yapılır? } & Biliyorum & 212 & 39,6 \\
\hline & Bilmiyorum & 324 & 60,4 \\
\hline \multirow{2}{*}{ Organ bağışında bulunmak ister misiniz? } & Evet & 250 & 46,6 \\
\hline & Hayır & 286 & 53,4 \\
\hline \multirow{2}{*}{$\begin{array}{l}\text { Ailenizde/çevrenizde organ nakli bekleyen hasta var } \\
\text { mı? }\end{array}$} & Var & 54 & 10,1 \\
\hline & Yok & 482 & 89,9 \\
\hline \multirow{2}{*}{ Ailenizde/çevrenizde organ nakli olan hasta var mı? } & Var & 52 & 9,7 \\
\hline & Yok & 484 & 90,3 \\
\hline \multirow{2}{*}{ Ailenizde organ bağışında bulunan kişi var mı? } & Var & 40 & 7,5 \\
\hline & Yok & 496 & 92,5 \\
\hline
\end{tabular}


Anket sorularına verilen cevaplar kendi aralarından anlamlılık açısından incelendiğinde; Ailesinde veya çevresinde organ nakli olan kişi bulunanlar, organ bağışında bulunmak istemekteydiler (p:0.002). Benzer şekilde, ailesinde veya çevresinde organ nakli bekleyen hastası olan kişiler ile ailesinde organ bağışı yapmış olan kişiler organ bağışında bulunmak istiyorlardı (p:0.011; p:0.000).

Doktor ve hemşire+sağl1k memuru grubu, organ bağışını personel grubuna göre anlamlı olarak daha doğru bir davranıș olarak görmekteydi (p:0.000 ; p:0.004). "Her ölen kișiden organ alınamaz." diyen doktorlar \%96,2 (n:128), personel \%87,5 (n:272) ve hemşire+sağllk memurları \%96,7 (n:89) oranında saptandı. Doktorlar ve hemşire+sağlık memuru grubu, her ölen kişiden organ alınamayacağını, personel grubuna göre daha doğru biliyordu (p:0.001).

Doktorların yakınları veya çevrelerinde organ nakli bekleyen hastası diğer gruplara göre anlamlı olarak daha azdı (p:0.025). Doktorlar ve hemşire+sağlık memuru grubunun "ailesinde organ bağışında bulunan kişi”, personel grubuna göre istatistiksel olarak anlamlı düzeyde daha fazlaydı (p:0.002 ; $\mathrm{p}: 0.045)$. Doktorlar ve hemşire+sağlı memurları, personelden daha fazla organ bağışında bulunmak istiyorlard1 (p:0.000; p:0.001).

\section{Tartışma}

Günümüzde organ nakli giderek daha fazla önem kazanmaktadır. Gerçekleştirilen organ nakillerine karşın bağışlanan organ sayısının yetersiz olması nedeniyle bağışlanan organlar ihtiyacı karşılamamaktadır. Bu çalışma tıp fakültesinde çalışanların organ bağışına karşı bilgi ve tutumlarını ortaya koymak amacıyla yapılmıştır.

Organ bağışının nasıl bir davranış olduğunu sorgulayan soruyla ilişkili olarak; Doğan ve arkadaşlarının yaptığı çalışmada öğrencilerin \%77'si organ bağışına olumlu bakarken, \%23'ü olumsuz görüş bildirmişlerdir (4). Çalışmamızda organ bağışına olumlu bakma oranı Doğan ve arkadaşlarının çalışmasına benzer çıkmıştır. Ankara'da üniversite öğrencileri ile yapılan bir araştırmada da, öğrencilerin $\% 41,5$ ' $\mathrm{i}$ beyin ölümü gerçekleşmesi durumunda yakınlarının organlarını bağışlayamayacağını belirtmiştir (19). Avrupa ülkelerinde ailelerin organ bağışını ret oranı yaklaşık \%30 civarındadır. Benzer kaygıların sadece ülkemizde değil diğer ülkelerde de olduğu görülmektedir (21). Organ bağışını onaylamamanın aynı temellere dayandığı gerçeği göz önüne alındığında; bu konuda toplumun aydınlatılmasının yanlış yargıları azaltacağını düşünmekteyiz.

Organ bağışı gerçekleşeceği zaman, organ bağışında bulunan kişinin önceden yazılı izin vermiş olması gerekmektedir. Bazı Avrupa ülkelerinde (Avusturya, Belçika, Portekiz, Fransa) yasalar adli vakalar hariç hayatta iken aksi bir durumu belgelememiş olan herkesi donör adayi olarak kabul etmektedir (presumed consent). Bu sistemde donör adayının ailesi veya yakınlarından izin alınması gerekmemektedir. Ülkemizde 2238 sayılı kanunda iznin nasıl alınacağı "Onsekiz yaşını doldurmuş mümeyyiz olan bir kişiden organ ve doku alınabilmesi için vericinin en az iki tanık huzurunda açık, bilinçli ve tesirden uzak olarak önceden verilmiş yazılı ve imzalı veya en az iki tanık önünde sözlü olarak beyan edip imzaladığı tutanağın bir hekim tarafından onaylanması zorunludur" şeklinde belirtilmektedir (3). Kanuna göre kişi organ bağışında bulunmuş olsa dahi (yasal olarak karşı çıkma hakları olmamalarına rağmen) organ ve doku ölüm anında yanında bulunan birinci derece yakınlarından birinin izniyle alınabilmektedir $(10,17,22)$. Ölen kişinin hayatta iken organ bağışı yapmasa bile bu konuda olumlu fikir beyan etmesi ailenin organ bağışı iznini vermesini kolaylaştırabilir. $\mathrm{Bu}$ nedenle konunun aile içinde sürekli gündemde tutulması önem taşımaktadır (18). Çalışmamızdaki kişilerin organ bağışlama kriterlerine verdikleri cevaplara bakıldığında; kişinin hayatta iken organlarını bağışlamış olması gerekir diyenler \%45,1, ailesinden izin almak gerekir diyenler \%26,9, herhangi bir izin almaya gerek yoktur diyenler \%1,9 ve hem ölen kişi organlarını bağışlamış olmalı hem de ailesinin izni olmalı diyenler $\% 58,6$ oranlarında bulunmuştur.

"Hangi organların ve dokuların naklinin gerçekleştirilebileceği" sorusu ile ilişkili olarak; Çan ve arkadaşlarının yaptığı çalışmada, çalışmaya katılanların \%88,8'si böbrek, \%66,1'i kornea, \%51'i karaciğer, \%43,7'si kalp, \%8,8'i kemik iliği, \%5,6's1 tüm organlar, \%0,6's1 deri, \%1,5'i diğer organların naklinin yapılabileceğini ifade etmişlerdir (23). Aktekin'in çalışmasında aynı soruya; 
çalışanların \%97,4'ü böbrek, \%90,6'sı karaciğer, \%87,4'ü kornea, \%83,3'ü kalp, \%33,3'ü kemik iliği, $\% 19,7$ 'si pankreas, \%14,4'ü akciğer ve \%1,0'i damar naklinin yapılabileceğini ifade etmişlerdir (24). Sarıtaş'ın uyguladığı ankette aynı soruya öğrencilerin \%70,7'si böbrek, \%57,8'i karaciğer, \%49,6's1 kalp, \%36's1 kornea, \%24,1'i kemik iliği, \%8,7'si akciğer, \%2,5'i deri ve \%2,2'si pankreas naklinin gerçekleştirilebileceğini ifade etmişlerdir (25). Bu çalışmalarda bizim çalışmamızla paralel olarak, verilen yanıtlar içinde böbrek nakli ilk sırayı almaktadır. Özellikle basın yayın organlarında çıkan haberlerin böbrek nakline yönelik haberlerden oluşmasının, bu durum üzerinde etkili bir faktör olduğu düşünülmektedir.

Organ bağışı konusunda toplum bilincinin yaratılmasının en iyi yolu okullarda eğitim verilmesidir (10). Özdağ'ın makalesinde, İngiltere ve İspanya'nın organ bağışı konusunda önde gelen ülkelerden oldukları ve bu ülkelerde organ bağışına ilişkin eğitime ilkokuldan başlandığı bildirilmektedir (26). Vinokur ve arkadaşları tarafından yapılan çalışmada öğrencilere organ bağışı konusunda yapılan eğitimin organ bağışına bakışlarının olumlu etkilendiği (27); Sanner tarafindan yapılan çalışmada öğrencilerin büyük bir kısmının (\%70) organ nakli ile ilgili konuların okul müfredatlarında yer alması gerektiğini ifade ettikleri belirlenmiştir (28). Organ bağışı konusunda bilgi edinme kaynaklarını belirlemeye yönelik yapılan çalışmalar incelendiğinde; Sanner'in yaptığı çalışmada öğrencilerin \%90'1; Gül ve arkadaşlarının sürücü kursuna başvuranlarla yaptığı çalışmada adayların \%40,8'i; Bölükbaş ve arkadaşlarının üniversite öğrencileri ile yaptı̆̆ 1 çalışmada öğrencilerin \%37,9'u; Akkış ve arkadaşlarının üniversite personeli ile yaptığı çalışmada personelin \%72'si; Özmen ve arkadaşlarının Meslek Sağlık Yüksekokulu öğrencileri ile yaptığı çalışmada öğrencilerin \%44'ü; Üstüner ve arkadaşlarının Sağlık Yüksek Okulu öğrencileri ile yaptığı çalışmada öğrencilerin \%66,7'si basın yayın organlarından, özellikle televizyondan, bilgi aldıklarını belirtmişlerdir $(16,28,29,30,31,32)$. Çalışmamıza katılan kişiler organ bağışıyla ilgili bildiklerini \%36,5 basın ve/veya yayın; \%18,5 okul ve/veya sağlık kuruluşları ve \%22 arkadaşlardan öğrendiklerini belirtmiştir. Organ bağışı ile ilgili olumsuz spekülasyonlar organ bağışını olumsuz yönde etkileyebilir. Bu olumsuzlukların ortadan kaldırılmasında da yine yayın organlarına, özellikle görsel medyaya, önemli görevler düşmektedir. Organ bağışını destekleyici programların yapılarak toplumun bilgilendirilmesi, toplum tarafindan sevilen sanatçılarla konunun işlenmesi bağış oranını önemli ölçüde arttırabilecektir.

Çan ve arkadaşlarının Trabzon il merkezinde yaptığı çalışmada bireylerin \%62,8'inin organlarını bağışlamayı düşündükleri tespit edilmiştir (23). Aytekin'in Antalya il merkezinde yaptığ 1 çalışmada araştırmaya katılan sağlık personelinin \%63,3'ü organ ve dokularını bağışlamak istemektedirler (24). Literatürde organ bağışı konusunda pek çok ülkede sıkıntıların yaşandığı ve halen istenilen düzeye ulaşılamadığı görülmektedir (33). Çalışmamıza katılan kişilerin \%46,6'sı organ bağışında bulunmak isterken; \%53,4'ü organ bağışında bulunmak istememektedir. Çalışmamızın sonuçları Aytekin'in çalışması ile benzerlik göstermektedir.

Doğan ve arkadaşlarının çalışmasında, öğrencilerin \%5,3'ünün organ nakli bekleyen yakını olduğu görülmüştür (4). Çalışmamızda ise bu oran \%10,1 olarak bulunmuştur.

Yılmaz ve arkadaşlarının araştırmasında "Organ bağışı nerede yapılır biliyor musunuz" sorusuna, çalışmaya katılanların \%43'ü "evet” derken, \%57'si "hayır” cevabını vermiştir (34). Çalışmamızda ise aynı soruya \%39,6 oranında "biliyorum" , \%60,4 oranında "bilmiyorum" cevabı verilmiştir. Her iki çalışmadaki sonuçlar benzer bulunmuştur.

\section{Sonuç}

Organ nakli ve bağışı ile ilgili mevzuat sağlık çalışanlarına aktarılmalı, yasal ve etik açıdan tüm boyutları açıklanmalıdır. Sağlık çalışanlarının konu ile ilgili bilgilenmesine önem verilmelidir. $\mathrm{Bu}$ eğitim meslek edinme süreci ve meslekte hizmet içi eğitim şeklinde devamlılık göstermelidir. Medya, organ nakli ve bağışı konusunda toplumu bilinçlendirmek amaçlı yayınlar yapmalı, konuyla ilgili gelişmeler topluma duyurulmalıdır. Ailelerin kişiler üzerindeki etkileri göz önünde tutularak ailelere konuyla ilgili bilgiler verilmeli ve aileler de organ bağısına teşvik edilmelidir. 
Şüphesiz ki başarılı organ-doku nakillerinin sayısının artması eğitim, bilinçlendirme ve bilgilendirme ile mümkün olacaktır. Bunun için, toplumun bu konudaki düşünceleri, bilgisi, varsa organ bağışını ve katılımlarını olumsuz yönde etkileyen faktörlerin belirlenmesi gerekmektedir.

\section{KAYNAKLAR}

[1] Sönmez Y, Zengin E, Ongel K, Kişioğlu N, Öztürk M. Attitude and Behavior Related to Organ Donation and Affecting Factors: A Study of Last-Term Students at a University. Transplant Proc 2010;42:1449-52.

[2] Organ ve Doku Nakli Hizmetleri Yönetmeliği, 25748 sayılı resmi gazete, 07.03.2005.

http://www.saglik.gov.tr/TR/belge/1-560/organ-ve-doku-nakli-hizmetleri-yonetmeligi.html Erişim tarihi: 01.08.2011

[3] Sağlık Bakanlığı Organ ve Doku Alınması, Saklanması ve Nakli Hakkında 2238 sayılı kanun, 29.05.1979.

http://www.saglik.gov.tr/TR/belge/1-445/tarihi29051979--sayisi2238--rg-tarihi03061979--rg-sayis-.html Erişim Tarihi:08.05.2011

[4] Doğan P, Toprak D. Organ nakli tanımı, kapsamı, dini ve kanuni yönü. Aile Hekimliği Dergisi 2009; 3(2):

[5] İnce N. Böbrek Nakli 2006 http://www.denizce.com/bobreknakli. Erişim tarihi: 14.08.2011.

[6] Organ Naklinin Tarihçesi. Türkiye Organ Nakli Derneği. http://www.tond.org.tr/ Erişim tarihi: 12.09.2011

[7] Organ ve Doku Nakli Hizmetleri. Bursa Sağlık Müdürlüğü. http://www.bsm.gov.tr/hiz_hast03.htm Erişim tarihi: 08.10.2011.

[8] Örer A, Oto Ö. Dünden Bugüne Kalp Cerrahisi. Türk Göğüs Kalp Damar Cerrahisi Dergisi 1999; 7(3):153160.

[9] Haberal Mehmet. http://mehmethaberal.baskent.edu.tr/index-tr.html Erişim tarihi: 08.10.2011.

[10] Yücettin L. (ed.) Organ Nakli Koordinasyonu El Kitabı. Eczacıbaşı İlaç Pazarlama, 2001; 5-7.

[11] Dontlu AÇ. Organ bağı̧ı ıe naklinde etik, dinsel ve yasal yaklaşımlar. Diyaliz Transplantasyon ve Yanık 2004; 15(2):69-76.

[12] Diyanet İşleri Başkanlığı Din İşleri Yüksek Kurulu 396 Sayılı Kararı, 1980.

http://www.diyanet.gov.tr/turkish/dy/Kurulkararlari.aspx?KonuId=1Erişim Tarihi:08.04.2009

[13] Sağlam T. Tüm yönleriyle organ bağışı http://arsiv.ntvmsnbc.com/news/464533.asp Erişim Tarihi:26.04.2011

[14] Bozoklar A. Donör Tespiti, Organ Nakli Koordinasyon El Kitabı, Antalya, 2001;38-40.

[15] Tokalak İ. Organ nakli koordinatörünün görev tanımı ve transplantasyon sürecindeki yeri. Diyaliz Transplantasyon Ve Yanık 2004; 15(1):1-6.

[16] Bölükbaş N, Eyüpoğlu A, Kurt P. Organ bağışı hakkında üniversite öğrencilerinin düşünceleri. Ondokuz Mayıs Üniversitesi Tip Dergisi 2004; 21(2):73-77.

[17] Organ Nakli Koordinatörler Derneği (ONKOD) internet sayfası. http://www.onkod.org Erişim Tarihi:26.04.2011

[18] Çolakoğlu M, Nalbant M. Transolantasyon için Denizli'den kadavra organ çıkarımı. Türk Nefroloji Diyaliz ve Transplantasyon Dergisi 2005; 14(3):123-126.

[19] Akgun S, Tokalak I, Erdal R. Attitudes and Behavior Related to Organ Donation and Transplantation: a Survey of University Students. Transplant Proc. 2002; 34(6):2009-2011.

[20] Schutte GR. 25 Years of Organ Donation: European Initiatives to Increase Organ Donation. Transplant Proc. 2002; 34(6):2005-2006.

[21] Chung CK, Ng CW, Li JY, et al. Attitudes, knowledge, and actions with regard to organ donation among Hong Kong medical students. Hong Kong Med J. 2008; 14(4):278-285. 